7. Reprod. Fert. (1975) 45, 129-138

\title{
NUCLEIC ACID METABOLISM OF CELLS OF THE LUMINAL EPITHELIUM AND STROMA OF THE RAT UTERUS DURING EARLY PREGNANCY
}

\author{
P. J. HEALD, J. E. O'GRADY, ANNE O'HARE AND \\ MAUREEN VASS \\ Medical Research Council Group for Biochemistry of Reproduction, \\ Department of Biochemistry, University of Strathclyde, 204 George Street, \\ Glasgow $G 11 \mathrm{XW}$
}

\section{(Received 30th December 1974)}

\begin{abstract}
Summary. The uptake of $\left[5-{ }^{3} \mathrm{H}\right]$ uridine into RNA and DNA of the cells of the uterine luminal epithelium, stroma and myometrium of the rat has been studied in early pregnancy using a technique for separation of the cell fractions before quantitative analysis. Comparisons of the metabolism between the pregnant and pseudopregnant horn of the unilaterally ovariectomized rat has shown that RNA and DNA synthesis are markedly increased by 04.00 hours on the morning of Day 5 in the pregnant horn. This increased metabolism occurs in all cell fractions and before the zona pellucida is shed. The results are discussed in relation to the onset of the decidual response.
\end{abstract}

\section{INTRODUCTION}

Increasing investigation during the last few years has led to the recognition of many endocrinological, structural and biochemical features which change immediately preceding and during the commencement of the implantation of the blastocyst in the rodent (De Feo, 1967; Tachi et al., 1970, 1972; Heald, 1973; O'Grady et al., 1974a; Finn \& Martin, 1974).

Thus it has been established in the rat that the cells of the luminal epithelium undergo mitosis principally on Day 2 whilst those of the stroma undergo mitosis on Day 4. This latter process appears to be a prerequisite to the subsequent redifferentiation of the stromal cells to form decidual cells in the presence of the trophoblast. Stromal cell division occurs in response to oestradiol following at least 36 to $48 \mathrm{hr}$ exposure to progesterone (Psychoyos 1966; Tachi et al., 1972) and it has been shown (Watson et al., 1975) that the level of plasma oestradiol in the pregnant rat increases between 20.00 hours on Day 3 and 06.00 hours on Day 4 of pregnancy. Agents which delay the increase in oestradiol by 20 to $24 \mathrm{hr}$ also delay stromal cell division and blastocyst implantation by a similar period (O'Grady et al., 1974b; Major \& Heald, 1974).

By 10.00 hours on Day 5 of pregnancy there is an increased synthesis of 
uterine RNA (Heald \& O'Grady, 1970), accompanied by an increased rate of processing of nuclear RNA (Heald $e t$ al., 1972a) and an increased synthesis of ribosomal RNA (Heald et al., 1972b) which almost ceases by 10.00 hours on Day 6 if implantation and decidualization do not occur. Further, the uterus on Day 5 by 09.00 hours contains a new species of RNA not detectable in decidualizing tissue on Day 7 or in the uterus on Day 2 (Heald \& O'Hare, 1973). The early stages of pregnancy are also accompanied by increased synthesis of total uterine protein (Reid \& Heald, 1970) and an increased activity of ornithine decarboxylase (Saunderson \& Heald, 1974). In the early decidualizing tissue the controlling glycolytic and pentose-shunt enzymes are increased (Surani \& Heald, 1971).

These results are in accord with a situation in which the stromal cells by the morning of Day 5 are able to respond to a stimulus (normally provided by the blastocyst) by redifferentiating to form decidual cells (see De Feo, 1967). The manner by which the blastocyst provides this stimulus is not known. Equally unknown is the earliest time at which the process of redifferentiation of the stromal cells is initiated. A major technical difficulty has been the necessity of working with whole uterine tissue but the development of a technique which permits the ready separation of the luminal epithelial and stromal cells into well-defined fractions (Heald et al., 1975) has enabled the latter problem to be approached more directly than hitherto.

Since the initiation of redifferentiation of cells is normally preceded by changes in RNA and DNA synthesis (see Mueller, 1971), measurements have been made of nucleic acid synthesis in the luminal epithelial and stromal cells of the pregnant rat uterus during Days 4 and 5.

\section{MATERIALS AND METHODS}

Rats were from a Holtzman-derived Sprague-Dawley strain maintained in windowless rooms on a lighting schedule of 06.00 to 20.00 hours and with free access to food and water. Animals were unilaterally ovariectomized at 10 weeks of age and were mated with proven males 3 to 4 weeks later. The morning on which spermatozoa were found in the vaginal smear was designated Day 1 of pregnancy.

Since implantation of the blastocyst occurs late on Day 5 in the rats of our colony (Major \& Heald, 1974), measurements were confined to the period between 09.00 hours on Day 4 to 21.00 hours on Day 5 .

Animals were lightly anaesthetized with ether and $100 \mu \mathrm{Ci}\left[5-{ }^{3} \mathrm{H}\right]$ uridine (sp. act. 27 to $28 \mathrm{Ci} / \mathrm{mmol}$ ) were injected into the femoral vein. The animals were killed $1 \mathrm{hr}$ later. The uterine horns were rapidly removed and luminal epithelial and stromal cell fractions, together with the myometrium, were prepared as described by Heald et al. (1975). Normally, two horns (from separate animals) were required to provide sufficient material for analysis. Analysis for RNA and DNA and determination of radioactivity in the fractions was carried out as described by Heald \& O’Grady (1970). 


\section{RESULTS}

\section{Metabolism of $R \mathcal{N A}$}

Uptake of uridine into total uterine RNA (Text-fig. 1) showed little difference between the two horns until 09.00 to 10.00 hours on Day 5 when the uptake into the pregnant horn was consistently higher than in the pseudopregnant horn. This difference declined by 22.00 hours. In the pregnant and the nonpregnant horn, the specific radioactivity of RNA in the cell fractions examined were similar and showed little increase between 09.00 hours and 21.00 to 22.00

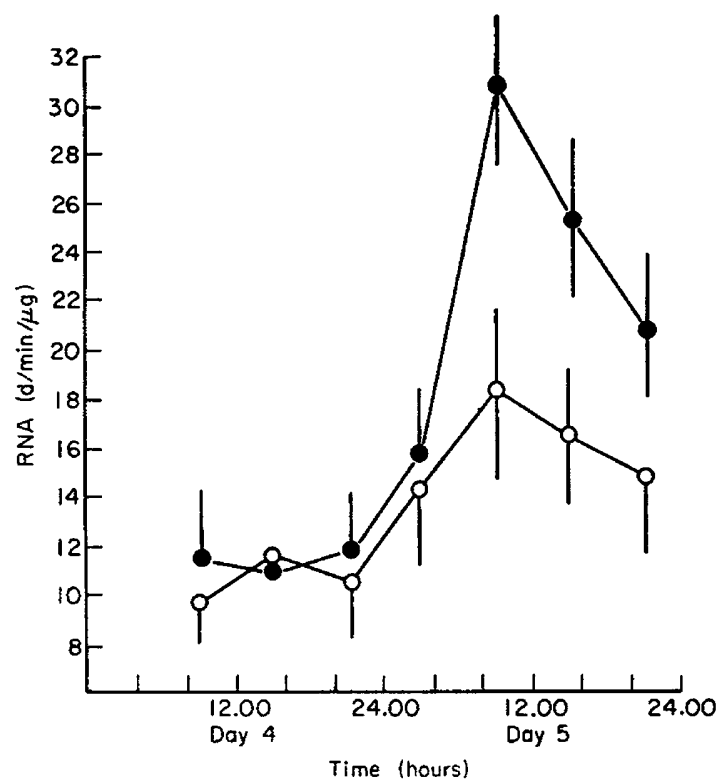

Text-Fig. 1. Incorporation of $\left[{ }^{3} \mathrm{H}\right]$ uridine into the pregnant $(\bullet)$ and contralateral pseudopregnant $(0)$ uterine horns of the rat. Each point represents the mean of determinations on at least four separate pairs of rats, and vertical lines indicate the limits of the S.E.M.

hours on Day 4 (Text-fig. 2). Commencing at 03.00 to 04.00 hours on Day 5, the radioactivity in the stromal cells and the myometrium rose and reached peak values by 09.00 hours. Activity in the luminal epithelial cells also rose by 09.00 hours on Day 5 , though not to the values obtaining in the stromal cells.

The specific radioactivities of the fractions from the pseudopregnant horns were lower than those from the pregnant horns. Paired comparisons showed that by 09.00 hours on Day 5 , the specific activity of the RNA in cell fractions from the pregnant horn was about $50 \%$ higher than those of the pseudopregnant horn, reaching a peak in the stromal and epithelial cells by 14.00 to 16.00 hours (Text-fig. 3). The pattern of change in the stromal cells was particularly marked with a significant $(P<0.01)$ decline in relative specific activity between 09.00 hours and 21.00 hours on Day 4 followed by a significant $(P<0.01)$ increase by 04.00 hours on Day 5 . 


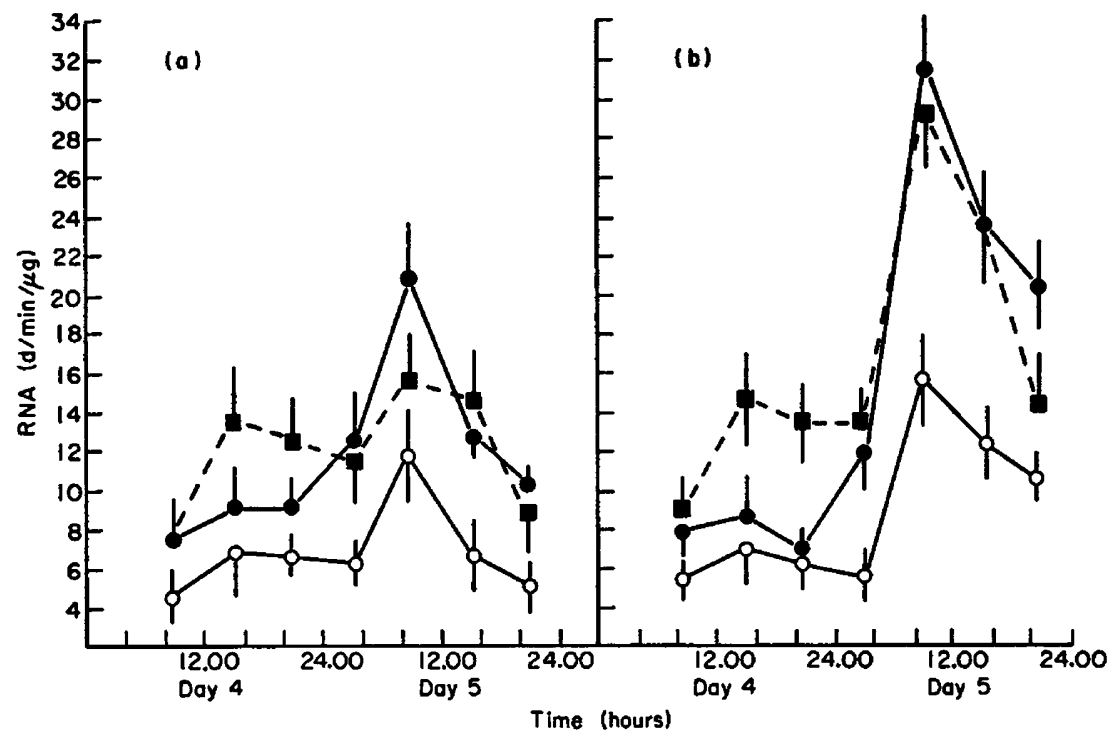

TexT-FIG. 2. Incorporation of $\left[{ }^{3} \mathrm{H}\right]$ uridine into the luminal epithelial (0), stromal (o) and myometrial ( $\square$ ) fractions of pregnant (b) and contralateral pseudopregnant (a) horns of the rat uterus. Each point represents the mean of determinations on at least four separate pairs of animals, and vertical bars represent the S.E.M.

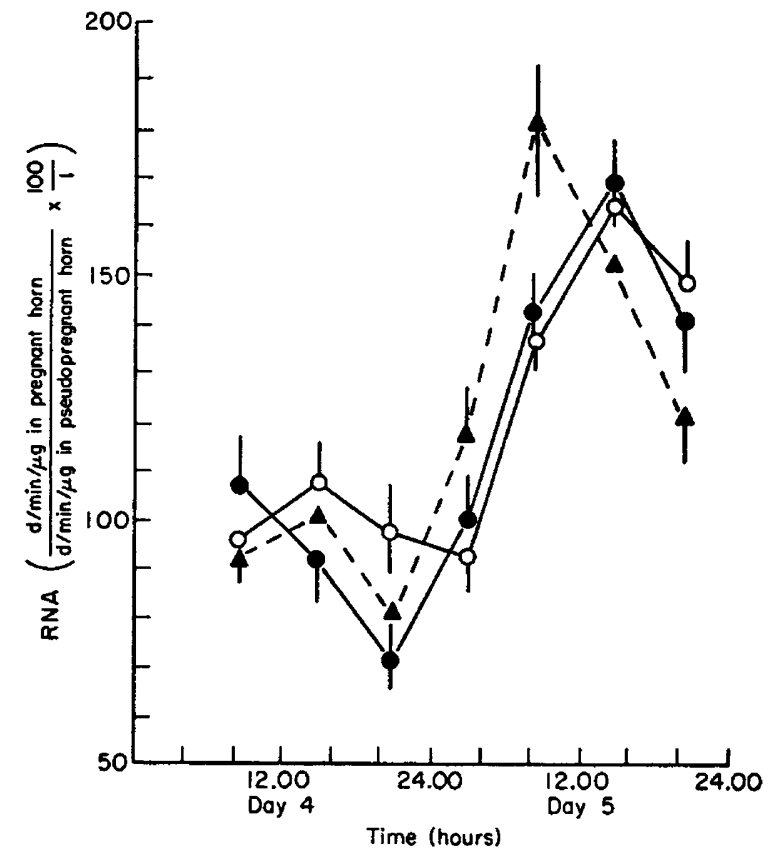

TexT-FIG. 3. Incorporation of $\left[{ }^{3} \mathrm{H}\right]$ uridine into cell fractions ( $\bullet$, stromal cells; $O$, epithelial cells; $\Delta$, myometrium) of the pregnant horn of the rat uterus as a percentage of incorporation into the contralateral pseudopregnant horn. Each point represents the mean of comparisons made in at least four pairs of rats, and vertical bars represent the S.E.M. 
Comparison of the ratios of the specific activities of the stromal to epithelial cells showed that this declined sharply in the pregnant horn until 21.00 to 22.00 hours on Day 4 but rose equally sharply by 03.00 hours on Day 5 and remained at this higher level. A similar change, though less marked on Day 4, was found in the pseudopregnant horn (Text-fig. 4).

The similarity of the ratio in the pregnant and pseudopregnant horns suggests that the increased RNA synthesis found in the pregnant horn occurred equally in both cell fractions of the pseudopregnant horn.

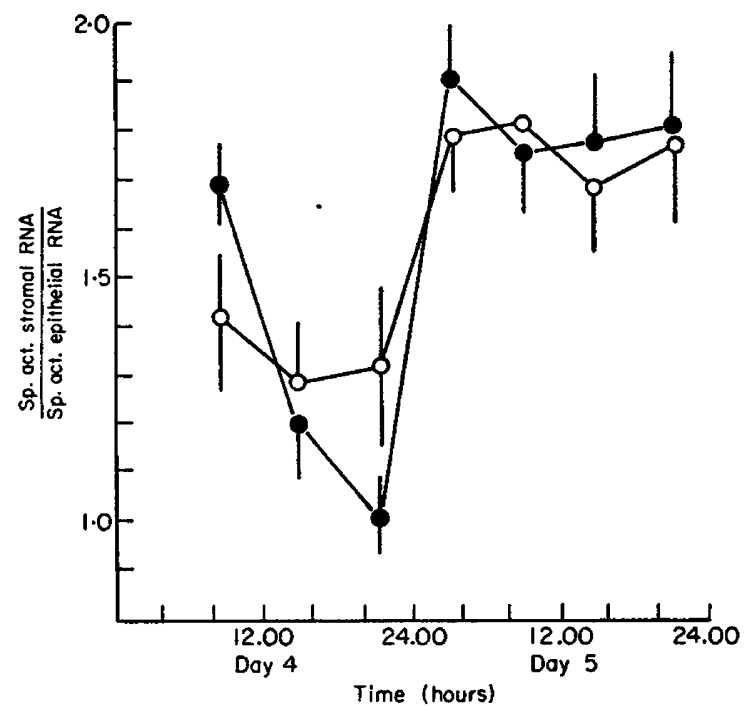

\begin{abstract}
TEXT-FIG. 4. Comparison of the ratios of the specific radioactivity of the RNA in the stromal and epithelial cells of the pregnant horn $(\bullet)$ and contralateral pseudopregnant horn $(0)$ of the rat uterus. Each point represents the mean of at least four determinations on separate pairs of animals, and vertical lines represent the S.E.M.
\end{abstract}

\title{
$D \mathcal{N} A$ metabolism
}

Since uridine is metabolized to cytidine and deoxycytidine, and, by way of dUMP, to dTMP, radioactivity from labelled uridine is normally incorporated into DNA.

The rate of appearance of the ${ }^{3} \mathrm{H}$ label from uridine in DNA was similar in the epithelial and stromal fractions of the pregnant and pseudopregnant horns until 03.00 to 04.00 hours on Day 5. At this time, uptake into DNA by the stromal cell fraction of the pregnant horn was greater than in the pseudopregnant horn and remained consistently so for the remainder of Day 5, the difference being significant $(0 \cdot 05>P>0.01)$ (Text-fig. 5).

Uptake into DNA in the epithelial cell fraction though increasing from Day 4 to Day 5 did not differ in the pregnant and pseudopregnant horns. No differences were found in uptake into the myometrium at any time, and throughout the experimental period the uptake, as measured by specific radioactivity, was low compared with that by the stroma and epithelium. 


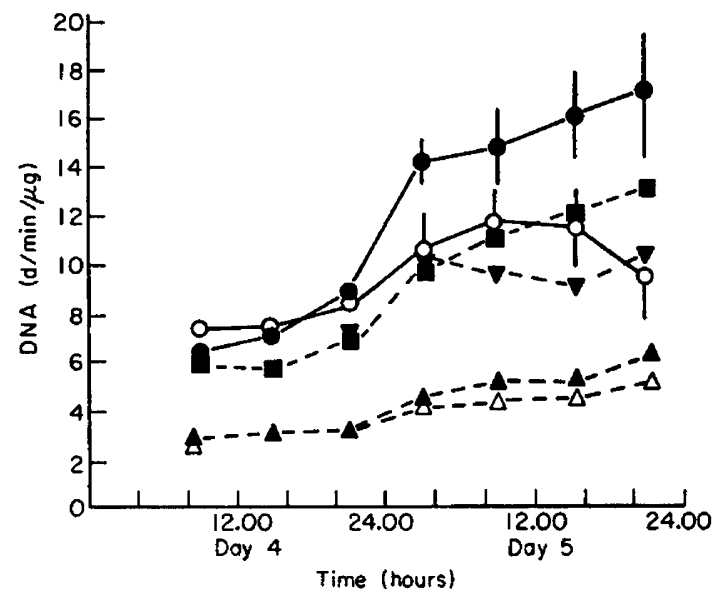

TEXT-FIG. 5. The incorporation of radioactivity from $\left[{ }^{3} \mathrm{H}\right]$ uridine into DNA in the luminal epithelial, stromal and myometrial cells of the pregnant and contralateral pseudopregnant horns of the rat uterus. Pregnant horn: e, stromal cells; $\square$, epithelial cells; $\boldsymbol{\Delta}$, myometrium. Pseudopregnant horn: $O$, stromal cells; $\nabla$, epithelial cells; $\Delta$, myometrium. Each point represents the mean of at least four pairs of animals, and vertical bars represent the S.E.M.

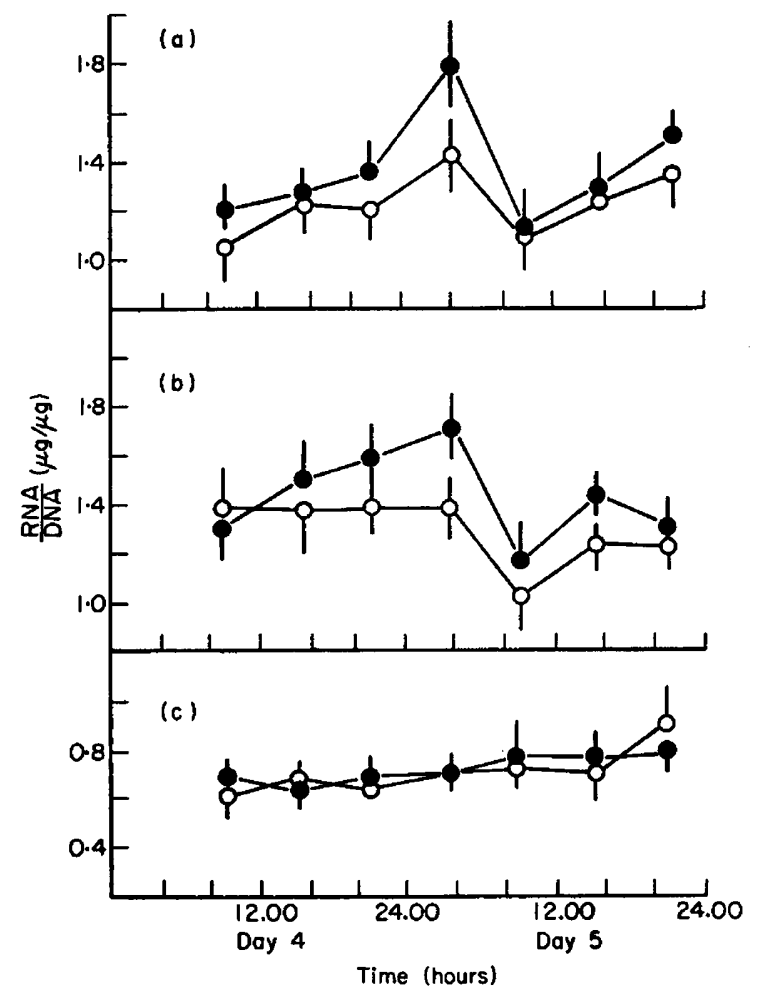

TExT-FIG. 6. The RNA:DNA ratios in the (a) epithelial, (b) stromal and (c) myometrial cells of the pregnant $(\bullet)$ and contralateral pseudopregnant $(O)$ horns of the rat uterus. Each point represents the mean of determinations on at least four separate pairs of rats, and vertical bars represent the S.E.M. 
The RNA/DNA ratios in the different fractions are presented in Text-fig. 6. Little difference existed between the ratios in the luminal epithelial cells of the pregnant and pseudopregnant horns except for the period 03.00 to 04.00 hours on Day 5 at which time the ratio in the pregnant horn was greater $(0.1>P>0.05)$ than in the pseudopregnant horn. In the stromal cells of the pregnant horn, the RNA/DNA ratios were similar to those of the pseudopregnant horn but during the period 20.00 hours on Day 4 to 04.00 hours on Day 5, the ratios in the pregnant horn were significantly $(P<0.01)$ higher than those of the pseudopregnant horn which did not alter.

\section{DISCUSSION}

The results show that synthesis of RNA in the whole uterus, the myometrium and in the cells of the luminal epithelium and the stroma is stimulated more in the pregnant horn than in the pseudopregnant horn shortly after 03.00 to 04.00 hours on the morning of Day 5 and is well advanced by 09.00 hours.

Table 1. The radioactivity of acid-soluble fractions of the total uterine tissue from the pregnant and pseudopregnant horns of rats

\begin{tabular}{|c|c|c|c|c|}
\hline \multirow[b]{2}{*}{ Day } & \multirow[b]{2}{*}{$\begin{array}{l}\text { Time } \\
(h r)\end{array}$} & \multicolumn{3}{|c|}{ Radioactivity (d/min/mg wet tissue) } \\
\hline & & $\begin{array}{l}\text { Pregnant } \\
\text { horn }\end{array}$ & $\begin{array}{l}\text { Pseudopregnant } \\
\text { horn }\end{array}$ & $\begin{array}{l}\text { Ratio pregnant: } \\
\text { pseudopregnant }\end{array}$ \\
\hline 4 & $\begin{array}{l}09.00-10.00 \\
15.00-16.00 \\
21.00-22.00\end{array}$ & $\begin{array}{l}747 \pm 56 \cdot 8(5) \\
850 \pm 62 \cdot 2(4) \\
815 \pm 34.9(5)\end{array}$ & $\begin{array}{l}726 \pm 66 \cdot 9(5) \\
847 \pm 45 \cdot 4(4) \\
791 \pm 34 \cdot 0\end{array}$ & $\begin{array}{l}1.04 \pm 0.064(5) \\
1.00 \pm 0.019(4) \\
1.03 \pm 0.04\end{array}$ \\
\hline 5 & $\begin{array}{l}03.00-04.00 \\
09.00-10.00 \\
15.00-16.00 \\
21.00-22.00\end{array}$ & $\begin{array}{l}807 \pm 49 \cdot 7(4) \\
886 \pm 63 \cdot 2(5) \\
951 \pm 78 \cdot 1(3) \\
768 \pm 42 \cdot 1(4)\end{array}$ & $\begin{array}{l}783 \pm 41 \cdot 5(4) \\
771 \pm 30 \cdot 5(5) \\
831 \pm 101(3) \\
779 \pm 77(3)\end{array}$ & $\begin{array}{l}1 \cdot 02 \pm 0.03(4) \\
1 \cdot 14 \pm 0 \cdot 05(5) \\
1 \cdot 15 \pm 0 \cdot 04(5) \\
0.96 \pm 0.02(3)\end{array}$ \\
\hline
\end{tabular}

Values are Means \pm S.E.M. Figures in parentheses represent the number of samples.

The perchloric-acid soluble material from weighed samples of whole uterine sections was counted for radioactivity as described by Heald \& O'Grady (1970).

This finding is in accord with the autoradiographic demonstration (Tachi et al., 1972) that $\left[{ }^{3} \mathrm{H}\right]$ uridine is incorporated into epithelial, stromal and myometrial cells of ovariectomized rats treated with oestradiol and progesterone. Synthesis of DNA is also significantly increased in the stromal cells of the pregnant horn by 03.00 to 04.00 hours on Day 5 but synthesis in the epithelial cells showed no significant change until 15.00 to 16.00 hours on Day 5. No difference was detected in DNA synthesis in the myometrium of the pregnant and pseudopregnant horns at any time studied.

The differences in specific radioactivities between the pregnant and pseudopregnant horns are unlikely to be due to differential permeability to uridine. Measurement of the acid-soluble radioactivity which represents the total tissue 
pool of uridine and nucleic acid precursors showed no difference between the pregnant and pseudopregnant horns sufficient to account for the difference in RNA and DNA synthesis (Table 1). Although such a measurement cannot determine the size of specific intracellular precursor pools, in the absence of any method for doing so, it represents a reasonable comparison.

In the rat, blastocysts enter the uterus during the afternoon of Day 4. In the preattachment stage at 11.00 hours on Day 5, the blastocyst is either free in the lumen or very loosely attached with the zona pellucida still intact (Tachi et al., 1970; Major \& Heald, 1974). The microvilli of the luminal epithelium are still present but contain many vacuoles (Tachi et al., 1970) and resemble in appearance the microvilli of the mouse luminal epithelium in the first stage of uterine closure in pregnancy (Pollard \& Finn, 1972, 1974). At this stage the subepithelial stromal cells have an evenly distributed chromatin with very little rough endoplasmic reticulum, but by 16.00 hours the stromal nuclei become smoother and more spherical, multiple nucleoli are common, and numerous polysomes appear in the subepithelial and midstromal region (Tachi et al., 1970). The trophoblast makes microscopically detectable contact with the luminal epithelium about 14.00 to 16.00 hours on Day 5 becoming intimately attached by 22.00 hours (Tachi et al., 1970). In the animals of our colony, this time coincides with the appearance of increased permeability to Niagra blue around the attachment site (see Psychoyos, 1966) in about $50 \%$ of pregnant animals, with $100 \%$ showing the reaction by 24.00 hours (Major \& Heald, 1974). These morphological changes have clearly been preceded by an increased biosynthesis of RNA and DNA and the stromal cells of the pregnant horn may be synthesizing increased quantities of RNA as early as 22.00 hours on Day 4 ('Text-fig. 6).

The changes in DNA synthesis are similar to those found by Tachi et al. (1972) who used $\left[{ }^{3} \mathrm{H}\right]$ thymidine for incorporation. Autoradiographic analysis (Tachi et al., 1972; Lobel et al., 1965) indicated that the label appeared predominantly in the stromal cells on Days 4 and 5 with little or none in either the luminal epithelial or glandular epithelial cells. Examination of the specific cell fractions in the present study showed that the increase in the pregnant horn on Day 5 is largely confined to the stromal cell fraction (Text-fig. 5). The uptake into the epithelial cell fraction was definite and too great to have arisen from potential contamination by the stromal cells and is therefore taken to represent a definite synthesis of DNA.

Synthesis of DNA and RNA in the stromal cells increases on Day 5, although proliferation of these cells has almost ceased. In the absence of implantation of the blastocyst, the stromal cells do not divide (Galassi, 1968) and the synthesis of nucleic acids in the whole uterus is suppressed (Heald \& O'Grady, 1970). Since increased RNA and DNA synthesis occur predominantly in the $S$ phase of the cell cycle, the results suggest that at least some of the stromal, and possibly also the epithelial, cells may become arrested in the $G_{2}$ phase (as postulated by Galassi, 1968) unless the stimulus deriving from the presence of the blastocyst has already initiated the mechanisms necessary for subsequent decidualization.

The nature of the stimulus is not known but it seems probable that it could be provided shortly after arrival of the blastocyst in the uterine lumen since the 
RNA:DNA ratios and RNA and DNA synthesis are elevated in the pregnant horn some 10 to $12 \mathrm{hr}$ after the arrival of the blastocyst. Although the presence of the blastocyst has been shown to stimulate uterine closure and redifferentiation of the luminal epithelium in the mouse (Pollard \& Finn, 1974), it seems unlikely that the early effects on uterine nucleic acid metabolism derive from such blastocyst secretions as the postulated transfer of RNA to endometrial stromal cells (Wilson \& Smith, 1968) or of other invasive material (see Finn \& McLaren, 1967; Finn \& Lawn, 1968), since these events follow after the shedding of the zona pellucida which occurs normally after 12.00 hours on Day 5 .

Although it might be suggested that the early increase in RNA synthesis, particularly in the stromal cells, is a preparation for subsequent decidualization, the present experiments do not permit any conclusions on this point. The most that can be stated is that nucleic acid metabolism in the pregnant horn is stimulated shortly after the arrival of the blastocyst in the uterus and before implantation commences, and be related to the synthesis of implantation initiating factors (Pinsker et al., 1974).

\section{ACKNOWLEDGMENT}

We thank the Medical Research Council for a grant (E. 863/1-2) to P.J.H.

\section{REFERENCES}

De Fzo, V.J. (1967) Decidualisation. In Cellular Biology of the Uterus, pp. 191-290. Ed. R. M. Wynn. North Holland Publishing Co., Amsterdam.

Fins, C.A. \& LAWN, A.M. (1968) Transfer of cellular material between the uterine epithelium and the trophoblast during the early stages of implantation. F. Reprod. Fert. 15, 333-336.

FinN, C.A. \& McLaren, A. (1967) A study of the early stages of implantation in mice. F. Reprod. Fert. 13, 259-267.

FinN, C.A. \& MARTin, L. (1974) The control of implantation. F. Reprod. Fert. 39, 195-206.

GaLASSI, L. (1968) Autoradiographic study of the decidual cell reaction in the rat. Devl Biol. 17, 75.

Heald, P.J. (1973) Uterine metabolism in early pregnancy in the rat. Trans. Biochem. Soc. 1, 487-491.

HEALd, P.J. \& O'GRADY, J.E. (1970) The uptake of $\left[{ }^{3} \mathrm{H}\right]$ uridine into the nucleic acids of the rat uterus during early pregnancy, Biochem. 7 . 117, 65-71.

Heald, P.J. \& O'HaRe, A. (1973) Changes in rat uterine nuclear RNA during early pregnancy. Biochim. biophys. Acta 324, 86-92.

Heald, P.J., O'Grady, J.E. \& Moffat, G.E. (1972a) The incorporation of $\left[{ }^{3} \mathrm{H}\right]$ uridine into nuclear RNA in the uterus of the rat during early pregnancy. Biochim. biophys. Acta 281, 347-352.

Heald, P.J., O'Grady, J.E., O'Hare, A. \& Vass, M. (1972b) Changes in uterine RNA during early pregnancy in the rat. Biochim. biophys. Acta 262, 66-74.

Heald, P.J., Govan, A.D.T. \& O'Grady, J.E. (1975) A simple method for the preparation of suspensions of luminal epithelial and stromal cells from rat uterus. 7. Reprod. Fert. 42, 593-585.

Lobel, B.L., Levy, L. \& Shelesnyak, M.C. (1965) Studies on the mechanism of nidation. XVII. Histochemical analysis of decidualization in the rat. Acta endocr., Copenh. 50, 468-485.

Major, J.S. \& Hxald, P.J. (1974) The effects of ICI 46,474 on ovum transport and implantation in the rat. F. Reprod. Fert. 36, 117-124.

Muelrer, G.C. (1971) Biochemical perspectives of the $G_{1}$ and $S$ intervals in the cycle of animal cells: a study in the control of cell growth. In The Cell Cycle and Cancer, pp. 269-307. Ed. R. Baserga. Marcel Dekker, New York.

O'Grady, J.E., Mofrat, G.E.M. \& Heal., P.J. (1974a) Uterine RNA metabolism in early pregnancy in the rat. 7 . Endocr. 61, i.

O'Grady, J.E., Armstrong, E., Moore, I. \& Vass, M. (1974b) The effect of Tamoxifen (ICI 46,474) on mitosis in the uterus of the rat during the early stages of pregnancy. F. Endocr. 63, 19p.

Pinsker, M.C., Succo, A.G. \& Mintz, B. (1974) A proteinase in the uterine fluid of the mouse associated with implantation. Devl Biol. 38, 285-290. 
Pollard, R.M. \& FinN, C.A. (1972) Ultrastructure of the mouse uterine epithelium during the hormonal induction of sensitivity and insensitivity to a decidual stimulus in the mouse. 7 . Endocr. 55, 293-298.

Pollard, R.M. \& Finn, C.A. (1974) Influence of the trophoblast upon differentiation of the uterine epithelium during implantation in the mouse. 7. Endocr. 62, 669-674.

Psychoyos, A. (1966) Recent researches on egg implantation. In Ciba Foundation Study Group, No. 23, pp. 4-14. Eds. G. E. M. Wolstenholme \& M. O'Connor. J. \& A. Churchill, London.

Reid, R.J. \& Heald, P.J. (1970) Uptake of $\left[{ }^{3} \mathrm{H}\right]$ leucine into proteins of rat uterus during early pregnancy. Biochim. biophys. Acta 204, 278-279.

Saunderson, R. \& Heald, P.J. (1974) Ornithine decarboxylase activity in the uterus of the rat during early pregnancy. 7. Reprod. Fert. 39, 141-143.

Surani, M.A.H. \& HeAld, P.J. (1971) Changes in enzymes of carbohydrate metabolism in rat uterus during early pregnancy. Acta endocr., Copenh. 68, 805-811.

TACHI, S., TACHI, G. \& LiNDNER, H.R. (1970) Ultrastructural features of blastocyst attachment and trophoblastic invasion in the rat. 7. Reprod. Fert. 21, 37-56.

TAChI, C., TAGH, S. \& Lindner, H.R. (1972) Modification by progesterone of oestradiol-induced cell proliferation, RNA synthesis and oestradiol distribution in the rat uterus. 7 . Reprod. Fert. 31, 59-76.

Watson, J., Anderson, F.B., Alam, M., O'Grady, J.E. \& Heald, P.J. (1975) Plasma hormones and pituitary luteinizing hormone in the rat during the early stages of pregnancy and following post-coital treatment with Tamoxifen ICI 46,474. 7. Endocr. 65, 7-17.

Wirson, I.B. \& Sмrтh, M.S.R. (1968) Isotopic labelling of the mouse blastocyst. F. Reprod. Fert. 16, 305-307. 